\title{
Synthesis of Highly Gas-Permeable Polyimides of Intrinsic Microporosity Derived from 1,3,6,8-Tetramethyl-2,7- diaminotriptycene
}

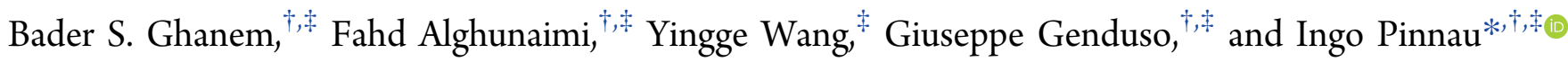 \\ ${ }^{\dagger}$ Functional Polymer Membranes Group and ${ }^{\ddagger}$ Advanced Membranes and Porous Materials Center, Division of Physical Sciences and \\ Engineering, King Abdullah University of Science and Technology (KAUST), Thuwal 23955-6900, Saudi Arabia
}

\section{Supporting Information}

ABSTRACT: A simple synthetic route to a novel sterically hindered triptycene-based diamine, 1,3,6,8-tetramethyl-2,7diaminotriptycene (TMDAT), and its use in the preparation of high molecular weight polyimides of intrinsic microporosity (PIM-PIs) are reported. The organosoluble TMDAT-derived polyimides displayed high Brunauer-Emmett-Teller surface areas ranging between 610 and $850 \mathrm{~m}^{2} \mathrm{~g}^{-1}$ and demonstrated excellent thermal stability of up to $510{ }^{\circ} \mathrm{C}$. Introduction of the rigid three-dimensional paddlewheel triptycene framework and the tetramethyl-induced restriction of the imide bond rotation resulted in highly permeable polyimides with moderate gas-pair selectivity. The best performing polyimide made from TMDAT and a triptycene-based dianhydride showed gas transport properties located between the 2008 and 2015 polymer permeability/selectivity trade-off curves with $\mathrm{H}_{2}$ and $\mathrm{O}_{2}$ permeabilities of 2858 and 575 barrer combined with $\mathrm{H}_{2} / \mathrm{N}_{2}$ and $\mathrm{O}_{2} / \mathrm{N}_{2}$ selectivities of 24 and 4.8, respectively, after 200 days of physical aging.

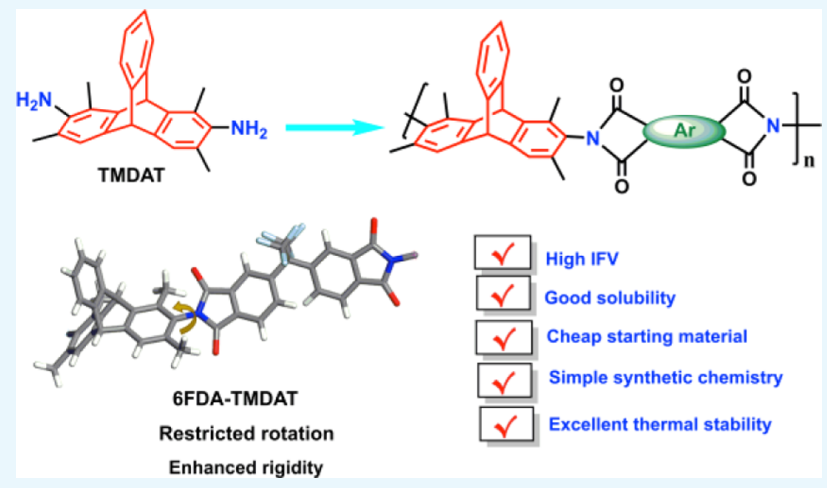

\section{INTRODUCTION}

Since their introduction in 2004, a wide variety of ladder polymers of intrinsic microporosity (PIMs) were intensively studied because of their potential commercial applications in catalysis, ${ }^{1-3}$ sensors for trace substance detection, ${ }^{4,5}$ gas storage, $^{6-8}$ nanofiltration, ${ }^{9,10}$ pervaporation, ${ }^{11,12}$ and most importantly membrane-based gas separations. ${ }^{13-29}$ The microporosity in these unique glassy ladder polymers was induced by design of nonplanar bulky contortion sites and the rigidity of the polymer chains that restricted efficient chain packing and, consequently, introduced high free volume with interconnected micropores $(<2 \mathrm{~nm}) .^{1-3}$

Aromatic polyimides are among the most promising materials for advanced gas separation membranes owing to their (i) excellent gas transport properties, (ii) exceptional thermal and chemical stability, (iii) high mechanical strength, (iv) good film-forming properties, and (v) flexible chemistry. ${ }^{30-35}$ Recently, polyimides of intrinsic microporosity (PIMPIs) were developed by introducing sterically hindered diamine- and/or dianhydride building blocks in the polymer backbone, including spirobisindane-, ethanoanthracene-, spirobifluorene-, Tröger's base-, carbocyclic pseudo Tröger's base-, and triptycene-derived units. ${ }^{36-56}$ PIM-PIs showed attractive gas separation properties for several important gas pairs with performance near or above the 2008 permeability/ selectivity Robeson upper bounds. ${ }^{57}$ Specifically, triptycene has been used as an attractive organic building block to construct
PIM-PIs because of its unique nonplanar three-dimensional (3D) rigid paddlewheel architecture comprising three benzene groups connected at $120^{\circ}$ around a $[2,2,2]$-tricyclic ring system. ${ }^{49}$ The rigidity and the nonplanar contortion site of the triptycene motif frustrate efficient polymer chain packing and generate high intrinsic internal free volume. ${ }^{49,50}$

Previous work showed that the introduction of orthosubstituted methyl groups in diamine monomers restricted the rotation of the imide linkages, thereby enhancing the rigidity, solubility, microporosity, and gas permeability of the corresponding polyimides. ${ }^{37-39,46,51,58}$ In extension to our previous work on triptycene-based PIM-PIs and to combine the potential of using the triptycene moiety and tetra-o-methyl substituents for the construction of new PIM-PI materials, here, we report a facile method for the synthesis of a novel 1,3,6,8-tetramethyl-2,7-diaminotriptycene (TMDAT) monomer. This new protocol has advantages of using a low-cost starting material, $m$-xylene, and simple synthetic chemistry to prepare solution-processable, high molecular weight triptycene-based PIM-PIs with enhanced porosity and gas permeability. The pure-gas permeation properties of a series of TMDAT-based PIM-PIs are reported for fresh and aged membrane samples.

Received: August 10, 2018

Accepted: September 12, 2018

Published: September 25, 2018 
Scheme 1. Detailed Synthetic Route for the Preparation of (a) TMDAT and (b) a Series of Intrinsically Microporous TMDATBased Polyimides Using Various Dianhydrides

(a)
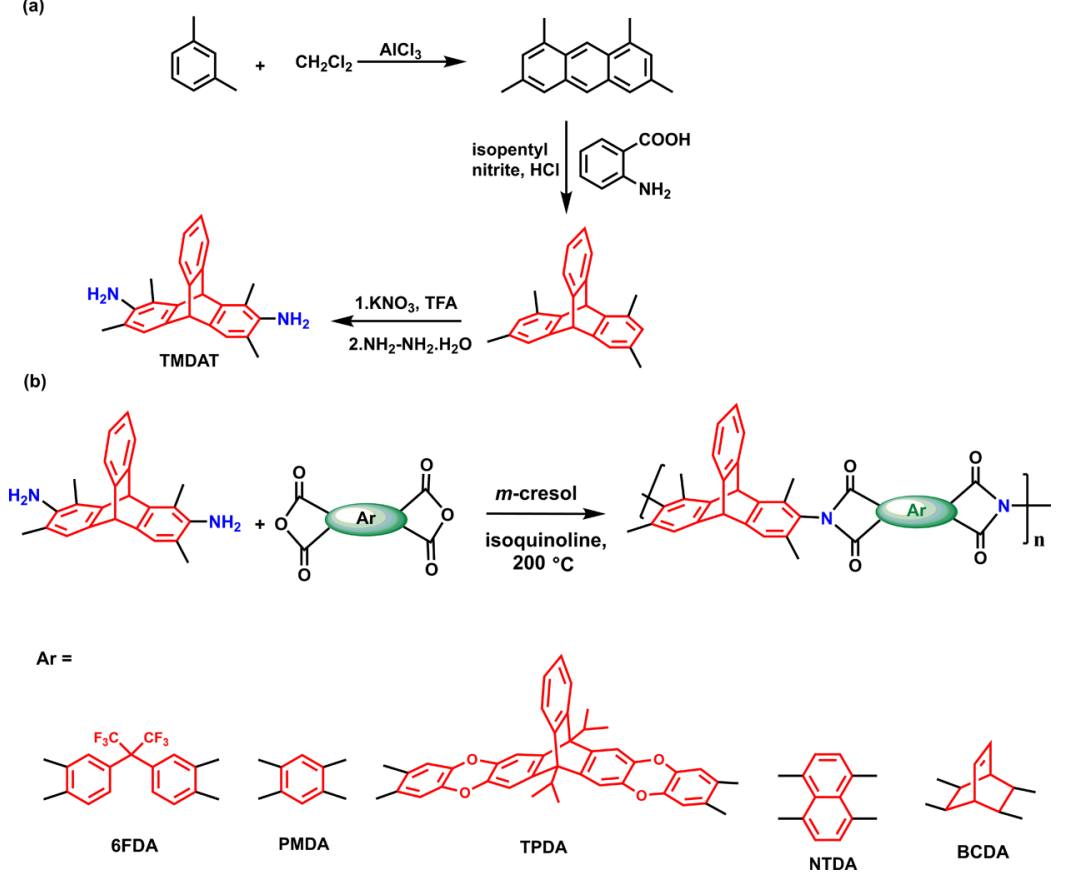

(a)

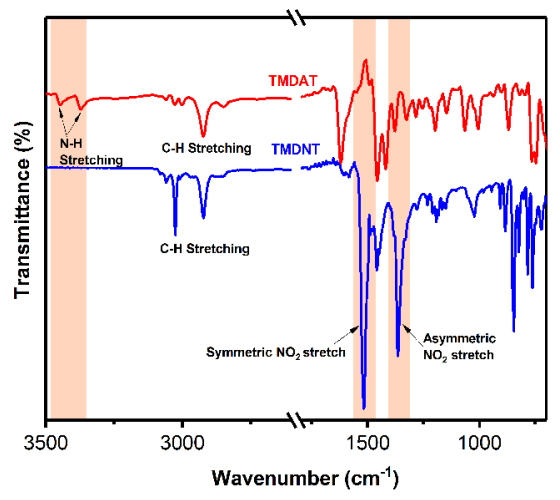

(b)

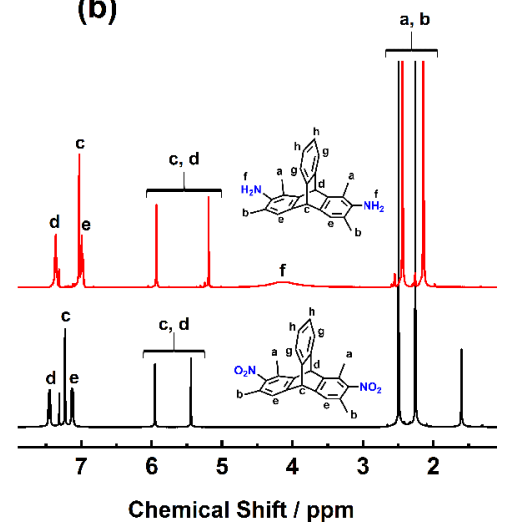

Figure 1. (a) FTIR spectra of TMDNT and TMDAT and (b) ${ }^{1} \mathrm{H}$ NMR spectra of TMDNT and TMDAT.

\section{RESULTS AND DISCUSSION}

2.1. Synthetic Route to TMDAT. The TMDAT monomer was synthesized by a simple synthetic route in four steps starting from $m$-xylene, as shown in Scheme 1a. The key intermediate 1,3,6,8-tetramethylanthracene (TMA) was obtained as a major product from the Friedel-Crafts alkylation reaction of $m$-xylene with dichloromethane (DCM) in the presence of aluminum chloride using the procedure reported by Ellison and Hey. ${ }^{59}$ The Diels-Alder reaction of tetramethylanthracene with the diazonium salt of 2-aminobenzoic acid yielded 1,3,6,8-tetramethyltriptycene (TMT). Nitration of TMA using potassium nitrate and trifluoroacetic anhydride followed by palladium-catalyzed hydrazine reduction of the dinitro intermediate [1,3,6,8-tetramethyl-2,7dinitrotriptycene (TMDNT)] yielded the diamine product TMDAT. The purity and molecular structures of all products were confirmed by standard characterization techniques, such as ${ }^{1} \mathrm{H}$ - and ${ }^{13} \mathrm{C}$ NMR, Fourier transform infrared (FTIR), and high-resolution mass spectroscopic analyses. The molecular structure of TMDNT was also confirmed by single-crystal Xray crystallography analysis.

The FTIR spectra of TMDNT and the TMDAT monomer are shown in Figure 1a. TMDAT showed characteristic absorption bands in the range of 3450, 3377, and $2943 \mathrm{~cm}^{-1}$ because of $\mathrm{N}-\mathrm{H}$ stretching vibrations of the amine groups and the $\mathrm{C}-\mathrm{H}$ stretching frequency of the methyl groups, respectively. The disappearance of the two characteristic absorption bands at 1515 and $1364 \mathrm{~cm}^{-1}$ assigned for the symmetric and asymmetric stretching frequency of the nitro groups in TMDNT confirmed the complete reduction to the diamine groups, respectively.

The ${ }^{1} \mathrm{H}$ NMR spectra for both TMDAT and TMDNT products confirmed their chemical structures and purity. As shown in Figure $1 \mathrm{~b}$, the signals at $(2.07,2.37)$ and $(2.21,2.44)$ ppm are assigned for the methyl protons of TMDAT and TMDNT, respectively. The protons of the amino groups appeared as broad singlet at $4.07 \mathrm{ppm}$. The signals assigned for the bridgehead protons of TMDAT and TMDNT appeared at $(5.12,5.86)$ and $(5.39,5.90) \mathrm{ppm}$, respectively. The molecular 
structure of TMDNT was further validated by single-crystal Xray crystallographic analysis (Figures 2 and S2), which confirmed the nonplanarity and 3D architecture of the triptycene moiety and the selective nitration at the 2,7positions of triptycene.

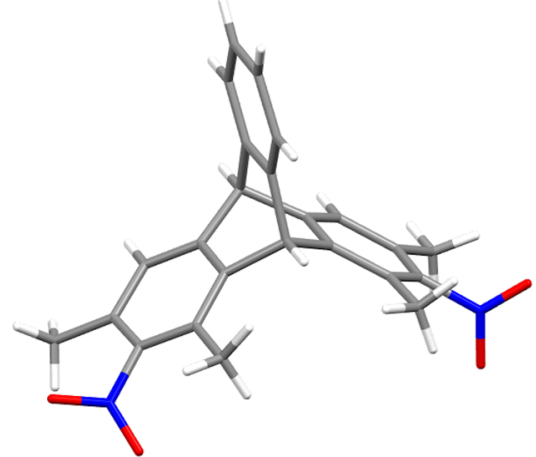

Figure 2. Molecular structure of TMDNT (CCDC 1515556).

2.2. Synthesis and Characterization of TMDAT-Based Polyimides. Five polyimides were prepared under nitrogen via a one-step high-temperature solution cycloimidization reaction of equimolar amounts of TMDAT and the aromatic dianhydride monomers in $m$-cresol containing two drops of isoquinoline, as shown in Scheme $1 \mathrm{~b}$. The polymers were characterized by ${ }^{1} \mathrm{H}$ NMR, FTIR, gel permeation chromatography (GPC), thermogravimetric analysis (TGA), and Brunauer-Emmett-Teller (BET) surface area measurements. The ${ }^{1} \mathrm{H}$ NMR spectra for all polymers were consistent with their proposed chemical structures. The ${ }^{1} \mathrm{H}$ NMR spectrum of a representative polyimide, 4,4'-(hexafluoroisopropylidene)diphthalic anhydride (6FDA)-TMDAT, is shown in Figure 3.

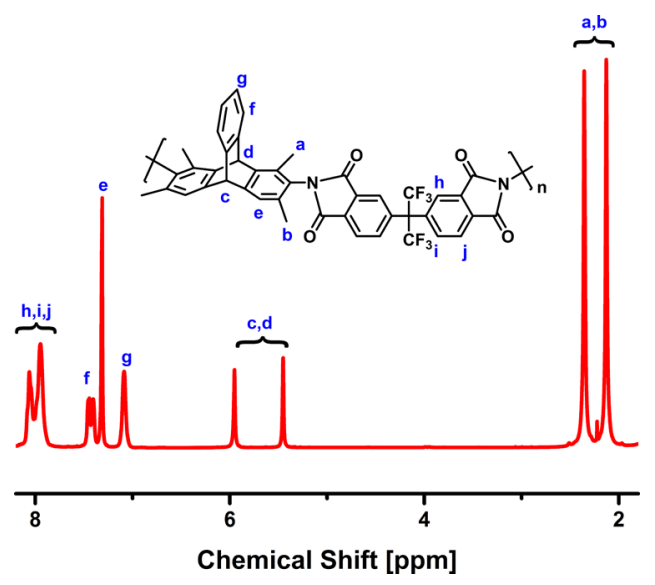

Figure 3. ${ }^{1} \mathrm{H}$ NMR spectrum of $6 \mathrm{FDA}-\mathrm{TMDAT}$ in $\mathrm{CDCl}_{3}$.

The two singlets at 2.08 and $2.30 \mathrm{ppm}$ each integrated for six protons were assigned to the methyl protons. The bridgehead protons appeared at 5.40 and $5.90 \mathrm{ppm}$, whereas the aromatic protons appeared in the range of 7.03-8.01 ppm. The complete imidization of the polyamic acid precursor was confirmed by the disappearance of the acid or amide signals at 10-12 ppm. The FTIR spectrum of 6FDA-TMDAT (Figure S1) showed two characteristic absorptions bands at 1787 and $1720 \mathrm{~cm}^{-1}$ assigned to asymmetric and symmetric stretching of imide carbonyl groups, respectively. Another band at 1374 $\mathrm{cm}^{-1}$ due to $\mathrm{C}-\mathrm{N}$ bond stretching further confirmed the formation of imide linkages. No peaks corresponding to polyamic acid were observed, indicating complete imidization. Gel permeation chromatographic measurements showed that the polyimides were prepared in high weight-average molecular weights $M_{\mathrm{w}}$ in the range of $122,000-192,000 \mathrm{~g} \mathrm{~mol}^{-1}$ and with narrow polydispersity index $\left(M_{\mathrm{w}} / M_{\mathrm{n}}\right)$ in the range of 1.4-1.6 (Table 1).

Table 1. Basic Properties of TMDAT-Based Polyimides

$\begin{array}{ccccc}\text { polymer } & M_{\mathrm{w}}{ }^{a}\left(\mathrm{~g} \mathrm{~mol}^{-1}\right) & \text { PDI }(-) & S_{\text {BET }}\left(\mathrm{m}^{2} \mathrm{~g}^{-1}\right) & T_{\mathrm{d}}{ }^{b}\left({ }^{\circ} \mathrm{C}\right) \\ \text { 6FDA-TMDAT } & 122,000 & 1.6 & 620 & 470 \\ \text { PMDA-TMDAT } & 125,000 & 1.5 & 720 & 500 \\ \text { TPDA-TMDAT } & 192,000 & 1.4 & 850 & 470 \\ \text { NTDA-TMDAT } & 156,000 & 1.5 & 790 & 510 \\ \text { BCDA-TMDAT } & 183,000 & 1.4 & 610 & 450\end{array}$

${ }^{a}$ Determined by GPC using chloroform (6FDA-TMDAT, PMDATMDAT, TPDA-TMDAT, and NTDA-TMDAT) or DMF (BCDATMDAT) as the eluent. ${ }^{b}$ Onset of the thermal decomposition temperature.

Aromatic polyimides derived from rigid planar dianhydrides such as pyromellitic dianhydride (PMDA) and 1,4,5,8naphthalenetetracarboxylic dianhydride (NTDA) generally show poor solubility in common organic solvents because of $\pi-\pi$ stacking of polymer chains, which results in strong interchain interactions. To improve their solubility, polyimides made from PMDA with nonplanar bulky diamines have shown significantly improved solubility. ${ }^{46,60}$ The TMDAT-derived PIM-PIs, including PMDA-TMDAT and NTDA-TMDAT, also displayed very good solubility in low- and high-boiling point organic solvents (Table S1) because of the nonplanarity of the 3D-paddlewheel triptycene architecture and the effect of the sterically restricted tetra-o-methyl substituents on the C$\mathrm{N}$-imide bond rotation. The thermal properties of the polymers were evaluated by TGA, demonstrating excellent thermal stability with onset decomposition temperatures between 450 and $510{ }^{\circ} \mathrm{C}$ in a $\mathrm{N}_{2}$ atmosphere (Figure 4, Table 1).

The microporosity of the TMDAT-based polyimides was evaluated by nitrogen adsorption analysis measured at -196 ${ }^{\circ} \mathrm{C}$ up to 1 bar (Figure 5). As previously demonstrated for other PIM-PIs, the introduction of sterically hindered $o$-methyl substituents to the imide linkages increased chain rigidity and

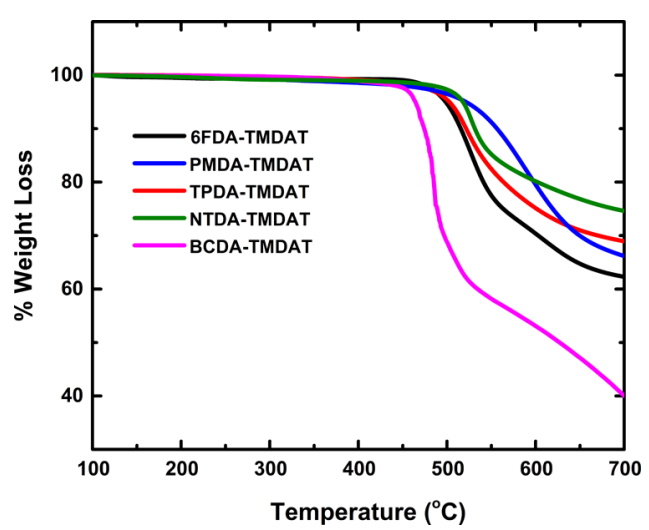

Figure 4. Thermal gravimetric analysis of TMDAT-based polyimides under a $\mathrm{N}_{2}$ atmosphere. 


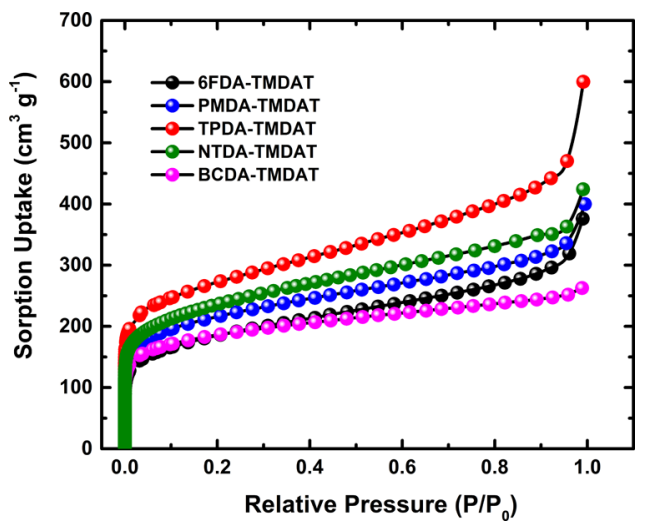

Figure 5. $\mathrm{N}_{2}$ adsorption isotherms of TMDAT-derived PIM-PIs measured at $-196^{\circ} \mathrm{C}$ up to 1 bar.

reduced efficient chain packing. ${ }^{37-39,46,51}$ All TMDAT-derived polyimides exhibited very high BET surface areas ranging from 610 to $850 \mathrm{~m}^{2} \mathrm{~g}^{-1}$ (Table 1), which rank among the highest values reported for PIM-PIs to date.

The pore size distributions of the TMDAT-based polyimides derived by NLDFT from nitrogen adsorption isotherms measured at $-196{ }^{\circ} \mathrm{C}$ are shown in Figure S3. The estimated pore sizes range between $\sim 5$ and $7.5 \AA$, as typically observed for PIM-PIs. The general trend of the pore size distributions of all polyimides is similar, which correlates qualitatively with their similar gas-pair selectivities for fresh film samples, as discussed below.

2.3. Gas Permeation Properties of PIM-PIs. Pure-gas permeabilities and ideal gas-pair selectivities for 1 day old samples of TMDAT-derived PIM-PIs measured at 2 bar and $35{ }^{\circ} \mathrm{C}$ are shown in Table 2 . It is well known that the gas transport properties of microporous polymers strongly depend on film preparation, film thickness, drying, and aging conditions. $^{62}$ Therefore, in this work, all polyimide films were made by the same methodology including a methanol treatment after an initial drying step to remove any residual casting solvent that has proven useful in obtaining reproducible gas permeation properties for fresh samples. The TMDATbased polyimides showed high gas permeabilities and moderate gas-pair selectivities regardless of the dianhydride type. For example, fresh PIM-PI samples made from TMDAT and conventional dianhydrides, 6FDA-TMDAT and PMDATMDAT, displayed $\mathrm{O}_{2}$ permeabilities of 374 and 680 barrer with $\mathrm{O}_{2} / \mathrm{N}_{2}$ selectivities of 3.3 and 3.8 , respectively. Notably, the PIM-PI made from the inexpensive PMDA-derived polyimide exhibited higher gas permeability without sacrificing selectivity when compared to 6FDA-TMDAT. This trend has also been demonstrated previously for 6FDA- and PMDAderived PIM-PIs made from tetramethyl-substituted Tröger's base diamine. ${ }^{46}$ It is interesting to compare the gas permeation properties of 6FDA-TMDAT with those of the previously reported 6FDA-DAT1, which was made from 6FDA and 2,6diaminotriptycene (DAT1). ${ }^{54}$ 6FDA-DAT1 exhibited a much lower BET surface area of $320 \mathrm{~m}^{2} \mathrm{~g}^{-1}$ than 6FDA-TMDAT $\left(620 \mathrm{~m}^{2} \mathrm{~g}^{-1}\right)$. Furthermore, 6FDA-DAT-1 displayed a much lower $\mathrm{O}_{2}$ permeability of 25.4 barrer but higher $\mathrm{O}_{2} / \mathrm{N}_{2}$ selectivity of 5.4 compared to 6FDA-TMDAT $\left(\mathrm{O}_{2}\right.$ permeability $=374$ barrer and $\mathrm{O}_{2} / \mathrm{N}_{2}=3.3$ ). Clearly, the enhanced permeability of 6FDA-TMDAT resulted from the tetramethylsubstitution that severely restricted the mobility of the imide linkages, resulting in higher free volume. Unfortunately, the desirable increase in permeability is coupled with a significant loss in selectivity, indicating undesirable effects in the pore size distribution that reduce the size-sieving properties of 6FDATMDAT.

Similar to other high surface area PIM-PIs, the gas permeability of fresh aromatic TMDAT-derived polyimide films increased in the following sequence: $\mathrm{PN}_{2}<\mathrm{PCH}_{4}<\mathrm{PO}_{2}$

Table 2. Gas Permeability and Selectivity of TMDAT-Derived Polyimides and Related Tetramethyl-Substituted Polyimides ( $T$ $=35{ }^{\circ} \mathrm{C} ; \boldsymbol{p}=2$ bar)

\begin{tabular}{|c|c|c|c|c|c|c|c|c|c|}
\hline \multirow[b]{2}{*}{ polymer } & \multicolumn{6}{|c|}{ pure-gas permeability (barrer) } & \multicolumn{3}{|c|}{ ideal selectivity $(\alpha)$} \\
\hline & $\mathrm{He}$ & $\mathrm{H}_{2}$ & $\mathrm{~N}_{2}$ & $\mathrm{O}_{2}$ & $\mathrm{CH}_{4}$ & $\mathrm{CO}_{2}$ & $\mathrm{CO}_{2} / \mathrm{CH}_{4}$ & $\mathrm{H}_{2} / \mathrm{N}_{2}$ & $\mathrm{O}_{2} / \mathrm{N}_{2}$ \\
\hline 6FDA-TMDAT ${ }^{a}$ & 758 & 1400 & 113 & 374 & 121 & 1727 & 14 & 12 & 3.3 \\
\hline 6FDA-TMDAT ${ }^{b}$ & $(601)$ & $(1024)$ & $(70)$ & $(261)$ & $(76)$ & $(1150)$ & $(15)$ & (15) & $(3.7)$ \\
\hline PMDA-TMDAT $^{a}$ & 1067 & 2375 & 180 & 680 & 238 & 3361 & 14 & 13 & 3.8 \\
\hline PMDA-TMDAT $^{b}$ & $(811)$ & $(1870)$ & $(134)$ & $(508)$ & $(171)$ & $(2380)$ & $(14)$ & (14) & $(3.8)$ \\
\hline TPDA-TMDAT $^{a}$ & 1695 & 4140 & 306 & 1153 & 395 & 5010 & 13 & 14 & 3.8 \\
\hline TPDA-TMDAT $^{b}$ & $(1300)$ & $(2858)$ & (119) & $(575)$ & $(135)$ & $(2321)$ & $(17)$ & (24) & $(4.8)$ \\
\hline NTDA-TMDAT $^{a}$ & 675 & 1484 & 97 & 390 & 122 & 1861 & 15 & 15 & 4 \\
\hline NTDA-TMDAT $^{c}$ & $(461)$ & (1053) & $(70)$ & $(281)$ & (89) & $(1441)$ & $(16)$ & (15) & (4) \\
\hline BCDA-TMDAT $^{a}$ & 692 & 1596 & 71 & 308 & 69 & 1313 & 19 & 22 & 4.3 \\
\hline BCDA-TMDAT $^{d}$ & $(467)$ & (1037) & $(46)$ & $(213)$ & (50) & $(1015)$ & $(20)$ & (23) & $(4.6)$ \\
\hline 6FDA-4MTBDA ${ }^{e}$ & & 1446 & 133 & 408 & 116 & 1672 & 14 & 10 & 3.1 \\
\hline 6FDA-4MTBDA ${ }^{f}$ & & $(964)$ & $(62)$ & $(229)$ & $(60)$ & $(1008)$ & 17 & 16 & 3.7 \\
\hline PMDA-4MTBDA $^{e}$ & & 3300 & 290 & 1080 & 390 & 4460 & 11 & 11 & 3.7 \\
\hline PMDA-4MTBDA $^{g}$ & & 1531 & 99 & 394 & 114 & 1689 & 15 & 15 & 4.0 \\
\hline TPDA-TMPD $^{h}$ & 1771 & 3983 & 107 & 627 & 105 & 2389 & 23 & 37 & 5.9 \\
\hline TPDA-TMPD ${ }^{i}$ (KAUST-PI-1) & & 3431 & 87 & 542 & & & & 39 & 6.2 \\
\hline 6FDA-TMPD ${ }^{j}$ & & 549 & 36 & 122 & 28 & 440 & 16 & 15 & 3.4 \\
\hline
\end{tabular}

${ }^{a}$ Air-dried film soaked in methanol for $24 \mathrm{~h}$, then dried under vacuum at $120{ }^{\circ} \mathrm{C}$ for $24 \mathrm{~h}$, and tested after 1 day. ${ }^{b}$ Tested after 200 days. ${ }^{c}$ Tested after 30 days. ${ }^{d}$ Tested after 60 days. ${ }^{e}$ From ref 46 , methanol-treated, air-dried, and tested after 1 day, $p=1$ bar, $T=25^{\circ} \mathrm{C} .{ }^{f}$ From ref 46 , tested after 524 days. ${ }^{g}$ From ref 46 , tested after 333 days. ${ }^{h}$ From ref 61 , methanol-treated, air-dried, and tested after 15 days. ${ }^{i}$ From ref 61 , tested after 150 days. ${ }^{j}$ From ref 58, no methanol treatment, dried at $200{ }^{\circ} \mathrm{C}, p=10$ bar, $T=35^{\circ} \mathrm{C}$. 
$<\mathrm{PHe}<\mathrm{PH}_{2}<\mathrm{PCO}_{2}$; the only exception in this series was the polyimide based on the cycloaliphatic dianhydride, bicyclo[2.2.2] oct-7-ene-2,3,5,6-tetracarboxylic dianhydride (BCDA), where $\mathrm{PH}_{2}>\mathrm{PCO}_{2}$, indicating a more dominating size-sieving behavior.

It is well known that the gas transport properties of microporous glassy polymers typically undergo a physical aging process during which the polymer free volume decreases with time because of chain rearrangement to tighter intra- and interchain packing. ${ }^{62}$ Consequently, physical aging leads to reduction in gas permeability as the polymer is slowly approaching its equilibrium chain configuration. Physical aging of 6FDA-TMDAT and PMDA-TMDAT films tested after 200 days resulted in $\sim 25-30 \%$ drop in $\mathrm{O}_{2}$ permeability with only small gain in $\mathrm{O}_{2} / \mathrm{N}_{2}$ selectivity. Interestingly, the most permeable PIM-PI in this series, TPDA-TMPDA, showed the largest relative decrease in $\mathrm{O}_{2}$ permeability of $\sim 50 \%$ from 1153 to 575 barrer after 200 days of aging, but $\mathrm{O}_{2} /$ $\mathrm{N}_{2}$ selectivity increased significantly from 3.8 to 4.8 . The loss in permeability with concomitant increase in selectivity is believed to be due to a relative increase in the fraction of ultramicropores $(<7 \AA)$ relative to larger micropores in TPDATMPDA.

The gas permeation properties of PIM-PIs previously made from other tetramethyl-substituted diamine building blocks, 2,8-diamino-1,3,7,9-tetramethyl-6H,12H-5,11-methanodibenzo- $[b, f][1,5]$ diazocine (4MTBDA) and 2,3,5,6-tetramethyl-pphenylene diamine (TMPD), are also listed in Table 2 . It is noteworthy to compare the gas permeation properties of 6FDA- and PMDA-derived polyimides made from 3D tetramethyl-substituted triptycene and Tröger's base diamines. It appears that polyimides made either from triptycene or Tröger's base PIM motif diamine building blocks with the same dianhydride had similarly high permeabilities coupled with moderate gas-pair selectivity. The effect of diamine building blocks on gas permeability in PIM-PIs can be further elucidated by comparing 6FDA-TMPD and the two polyimides containing 3D-PIM motifs, 6FDA-TMDAT and 6FDA4MTBDA. Clearly, the planar 6FDA-TMPD exhibits about $50 \%$ lower permeability with similar selectivity values compared to the 3D-type triptycene and Tröger's base polyimides. The notable exception in this series of tetramethyl-substituted polyimides (KAUST-PI-1) is based on a previously reported triptycene-based dianhydride (TPDA) and planar TMPD, which showed an exceptional combination of gas permeability and gas-pair selectivity because of high intrinsic microporosity and significant fraction of ultramicroporosity. ${ }^{51}$

The performance of the TMDAT-based polyimide series for $\mathrm{O}_{2} / \mathrm{N}_{2}$ and $\mathrm{H}_{2} / \mathrm{N}$ separation is summarized and compared to other tetramethyl-substituted polyimides in Figure 6. Clearly, TPDA-TMPDA is the most promising candidate membrane material with performance between the 2008 and $2015 \mathrm{O}_{2} / \mathrm{N}_{2}$ and $\mathrm{H}_{2} / \mathrm{N}_{2}$ permeability/selectivity trade-off curves. On the other hand, although the TMDAT-based polyimides showed very high $\mathrm{CO}_{2}$ permeability (>1000 barrer), their applicability for viable $\mathrm{CO}_{2} / \mathrm{CH}_{4}$ separation in natural gas or biogas treatment is unlikely because of their modest pure-gas $\mathrm{CO}_{2}$ / $\mathrm{CH}_{4}$ selectivity of $<20$.

$1=6$ FDA-TMDAT; 2 = PMDA-TMDAT; 3 = TPDATMDAT; 4 = NTDA-TMDAT; 5 = BCDA-TMDAT; $6=$ 6FDA-4MTBDA; 7 = PMDA-4MTBDA; $8=$ TPDA-TMPD (KAUST-PI-1); 9 = 6FDA-TMPD.
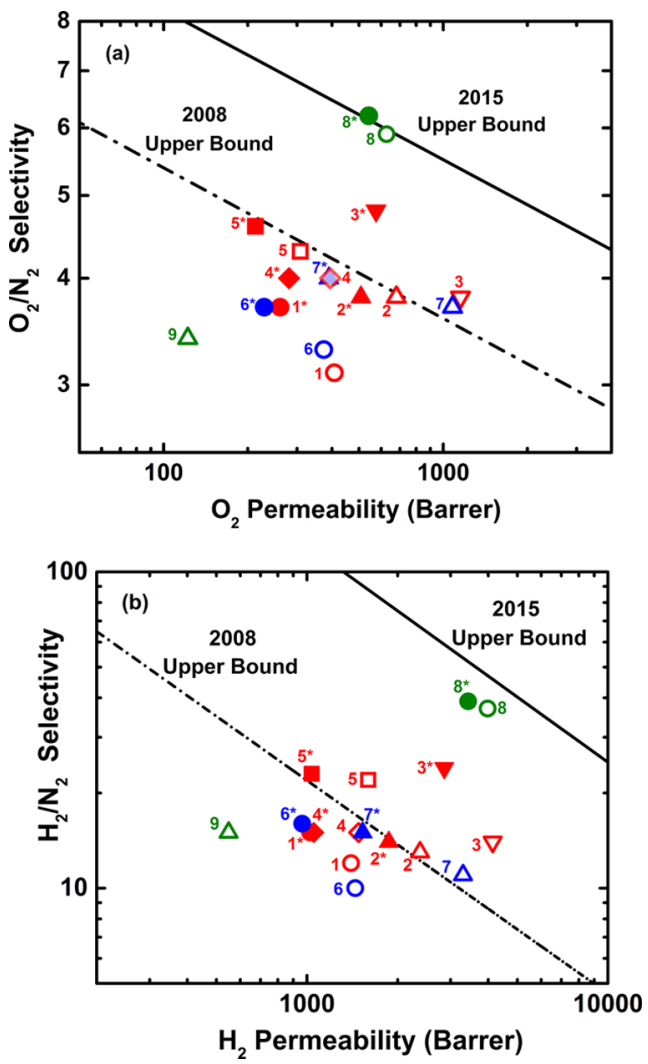

Figure 6. Location of PIM-PIs derived from tetramethyl-substituted polyimides relative to $2008^{57}$ and $2015^{63}$ permeability/selectivity upper bounds for fresh (open symbols) and aged samples (closed symbols) for: (a) $\mathrm{O}_{2} / \mathrm{N}_{2}$ and (b) $\mathrm{H}_{2} / \mathrm{N}_{2}$. Data from Table 2. Red symbols: TMDAT-based polyimides; blue symbols: 4-MTBDA-based polyimides; green symbols: TMPD-based polyimides.

\section{CONCLUSIONS}

In this study, a series of PIM-PIs was successfully prepared by a conventional one-step high temperature cycloimidization reaction of a novel, sterically highly contorted triptycenebased diamine, TMDAT, with five different dianhydrides (6FDA, PMDA, TPDA, NTDA, and BCDA). The polyimides exhibited high molecular weight $\left(M_{\mathrm{w}}>100,000 \mathrm{~g} \mathrm{~mol}^{-1}\right)$, excellent solubility in organic solvents, and high thermal stability. Intrinsic microporosity of the polyimides was demonstrated by high BET surface area values $\left(610-850 \mathrm{~m}^{2}\right.$ $\left.\mathrm{g}^{-1}\right)$. All polymers showed high gas permeabilities with moderate gas-pair selectivities. Interestingly, the most permeable polyimide in this series, TPDA-TMDAT, also displayed the highest gas-pair selectivities with performance located between the 2008 and 2015 permeability/selectivity trade-off curves for $\mathrm{O}_{2} / \mathrm{N}_{2}$ and $\mathrm{H}_{2} / \mathrm{N}_{2}$ separations.

\section{EXPERIMENTAL SECTION}

4.1. Materials. Potassium nitrate, $m$-xylene, acetonitrile, trifluoroacetic anhydride, hydrazine monohydrate, $\mathrm{Pd} / \mathrm{C}$ catalyst (10 wt \%) isoquinoline, anthranilic acid, and isopentyl nitrite were obtained from Aldrich and used as received. PMDA and 6FDA were purchased from Aldrich and purified by sublimation under vacuum prior to use. Sublimed NTDA and BCDA were obtained from TCI (America). 9,10Diisopropyl-triptycene dianhydride (TPDA) monomer was prepared according to a previously reported procedure. ${ }^{51} \mathrm{~m}$ Cresol was purchased from Aldrich and dried over $4 \AA$ 
molecular sieves. All other solvents were obtained from various commercial sources and used as received.

4.2. Characterization. ${ }^{1} \mathrm{H}$ NMR and ${ }^{13} \mathrm{C}$ NMR spectra for all monomers and polymers were obtained with a Bruker AVANCE-III spectrometer at a frequency of 400 or $500 \mathrm{MHz}$ in deuterated chloroform $\left(\mathrm{CDCl}_{3}\right)$ or dimethylsulfoxide $\left(\right.$ DMSO- $\left.d_{6}\right)$. FTIR measurements were performed using a Varian 670-IR FTIR spectrometer. Single-crystal X-ray data were collected at $140(2) \mathrm{K}$ using a Bruker D8 Venture diffractometer equipped with a PHOTON 100 CMOS area detector and a $\mathrm{Cu}(\mathrm{K} \alpha)$ source, $\lambda=2.54 \AA$. Yellow crystals of TMDNT suitable for X-ray diffraction were obtained by slow evaporation from solution in $n$-hexane/DCM (3:1) after 2 days. Column chromatography was carried out on silica gel 60A. Molecular weights $\left(M_{\mathrm{w}}\right.$ and $\left.M_{\mathrm{n}}\right)$ of the polymers were determined by gel permeation chromatography using chloroform $\left(\mathrm{CHCl}_{3}\right)$ or $\mathrm{N}, \mathrm{N}$-dimethylformamide (DMF) as eluents (GPC, Viscotek and Agilent 1200) and polydisperse polystyrene as the external standard. High-resolution mass spectroscopy (HRMS) was conducted on a Thermo LC/MS system with LTQ Orbitrap Velos detectors. The onset thermal decomposition temperatures of the polymers were determined by TGA (TA Q-5000) under nitrogen flow at a heating rate of $3{ }^{\circ} \mathrm{C} \mathrm{min}{ }^{-1}$ from room temperature to $700{ }^{\circ} \mathrm{C}$. The BET surface area of the polymers was determined by nitrogen adsorption at $-196{ }^{\circ} \mathrm{C}$ up to 1 bar using Micromeritics ASAP2020 equipped with micropore option. Prior to analysis, powder samples were degassed under high vacuum at $150{ }^{\circ} \mathrm{C}$ for $24 \mathrm{~h}$.

4.3. Synthesis of TMA. TMA was prepared according to the previously reported procedure by Ellison and Hey. ${ }^{59}$ To a stirred mixture of anhydrous $m$-xylene $(200 \mathrm{~mL})$ and $\mathrm{AlCl}_{3}(60$ g, $0.44 \mathrm{~mol})$ was added DCM $(37.6 \mathrm{~mL})$ for a period of $1 \mathrm{~h}$. After heating at $60{ }^{\circ} \mathrm{C}$ for $3 \mathrm{~h}$, the temperature was raised to 80 ${ }^{\circ} \mathrm{C}$ and maintained at this temperature for $5 \mathrm{~h}$. The reaction mixture was quenched with crushed ice and steam-distilled to remove excess $m$-xylene. The residual solid was extracted with hot ethanol and boiled with charcoal and filtered to give the desired product in $23 \%$ yield. Melting point $=296-298{ }^{\circ} \mathrm{C} .{ }^{1} \mathrm{H}$ NMR (400 MHz, $\left.\mathrm{CDCl}_{3}, \delta\right): 2.48(\mathrm{~s}, 6 \mathrm{H}), 2.76(\mathrm{~s}, 6 \mathrm{H}), 7.11$ $(\mathrm{s}, 2 \mathrm{H}), 7.56(\mathrm{~s}, 2 \mathrm{H}), 8.16(\mathrm{~s}, 1 \mathrm{H}) ; 8.47(\mathrm{~s}, 1 \mathrm{H}) .{ }^{13} \mathrm{C} \mathrm{NMR}$ $\left(100 \mathrm{MHz}, \mathrm{CDCl}_{3}, \delta\right): 19.8,22.1,118.8,124.8,125.5,128.4$, $129.5,132.3,134.4,134.7$. HRMS (ESI) $(\mathrm{m} / z)$ : calcd for $\mathrm{C}_{18} \mathrm{H}_{18}, 234.1409$; found, $234.1403\left(\mathrm{M}^{+}\right)$.

4.4. Synthesis of TMT. To an ice-cooled anthranilic acid $(15.00 \mathrm{~g}, 36.0 \mathrm{mmol})$ solution in ethanol $(150 \mathrm{~mL})$ were added concentrated $\mathrm{HCl}(12.6 \mathrm{~mL})$ and isopentyl nitrite (31 $\mathrm{mL}$ ) under stirring. After $15 \mathrm{~min}$, diethyl ether $(200 \mathrm{~mL})$ was added and the reaction mixture was stirred for additional 15 min. The resulting diazonium salt was then filtered, washed with ether, and dried in a vacuum aspirator and added in portions to a hot solution of TMA $(4.81 \mathrm{~g}, 17.83 \mathrm{mmol})$ in dichloroethane $(120 \mathrm{~mL})$ and 1,2-epoxypropane $(15 \mathrm{~mL})$. The reaction mixture was refluxed under a nitrogen atmosphere for $10 \mathrm{~h}$, and the solvent was then removed under vacuum. After the crude product was subjected to column chromatography (silica gel, $n$-hexane), the desired product was obtained as white crystals in $50 \%$ yield. Melting point $=191-193{ }^{\circ} \mathrm{C} .{ }^{1} \mathrm{H}$ NMR (400 MHz, $\left.\mathrm{CDCl}_{3}, \delta\right): 2.19(\mathrm{~s}, 6 \mathrm{H}), 5.46(\mathrm{~s}, 6 \mathrm{H}), 5.26$ $(\mathrm{s}, 1 \mathrm{H}), 5.80(\mathrm{~s}, 1 \mathrm{H}), 6.62(\mathrm{~s}, 2 \mathrm{H}), 6.93-6.97(\mathrm{~m}, 2 \mathrm{H}), 7.04$ (s, 2H), 7.31-7.36 (m, 2H). ${ }^{13} \mathrm{C}$ NMR $\left(100 \mathrm{MHz}, \mathrm{CDCl}_{3}, \delta\right)$ : 18.7, 21.2, 46.1, 54.9, 122.5, 123.6, 123.7, 125.1, 125.3, 127.3,
131.5, 134.4, 141.0, 145.5, 146.0, 146.2. HRMS (ESI) $(m / z)$ : calcd for $\mathrm{C}_{24} \mathrm{H}_{22}, 310.1722$; found, $310.1716\left(\mathrm{M}^{+}\right)$.

4.5. Synthesis of TMDNT. Trifluoroacetic anhydride $(7.06$ g, $33.61 \mathrm{mmol}$ ) was added dropwise to a mixture of TMT $(1.47 \mathrm{~g}, 4.74 \mathrm{mmol})$, potassium nitrate $(0.99 \mathrm{~g}, 9.67 \mathrm{mmol})$, and acetonitrile $(55 \mathrm{~mL})$. After stirring at room temperature for $20 \mathrm{~h}$, the reaction mixture was added to $600 \mathrm{~mL}$ water. The resulting precipitate was purified by column chromatography on silica gel with $n$-hexane/DCM 4:1 (eluent) to give the dinitro product as a pale yellow powder $(0.95 \mathrm{~g}, 67 \%$ yield $)$. Melting point $=326-328{ }^{\circ} \mathrm{C} .{ }^{1} \mathrm{H}$ NMR $\left(400 \mathrm{MHz}, \mathrm{CDCl}_{3}, \delta\right)$ : $2.21(\mathrm{~s}, 6 \mathrm{H}), 2.44(\mathrm{~s}, 6 \mathrm{H}), 5.39(\mathrm{~s}, 1 \mathrm{H}), 5.90(\mathrm{~s}, 1 \mathrm{H}), 7.06-$ $7.08(\mathrm{~m}, 2 \mathrm{H}), 7.18(\mathrm{~s}, 2 \mathrm{H}), 7.38-7.41(\mathrm{~m}, 2 \mathrm{H}) .{ }^{13} \mathrm{C}$ NMR $\left(100 \mathrm{MHz}, \mathrm{CDCl}_{3}, \delta\right): 13.9,17.5,46.5,54.3,124.1,124.2$, $124.5,126.2,126.4,127.0,142.4,143.3,143.8,146.5,149.9$. HRMS (ESI) $(m / z)$ : calcd for $\mathrm{C}_{24} \mathrm{H}_{20} \mathrm{~N}_{2} \mathrm{O}_{4}, 400.1423$; found: 400.1418. FTIR (powder, $\nu, \mathrm{cm}^{-1}$ ): 1515, 1364 (symmetric and asymmetric- $\mathrm{NO}_{2}$ stretching), $846(\mathrm{C}-\mathrm{N}$ stretching for aromatic $-\mathrm{NO}_{2}$ ).

4.6. Synthesis of TMDAT. Hydrazine hydrate $(5.4 \mathrm{~mL}$, $171.9 \mathrm{mmol})$ was added to a stirred mixture of TMDNT $(1.52$ $\mathrm{g}, 2.07 \mathrm{mmol})$ and palladium/carbon $(0.45 \mathrm{~g}, 10 \%)$ in absolute ethanol $(120 \mathrm{~mL})$. After refluxing for $6 \mathrm{~h}$, the cooled mixture was filtered into stirred water $(700 \mathrm{~mL})$. The resulting white solid was dried under vacuum at $110{ }^{\circ} \mathrm{C}$ for $20 \mathrm{~h}$ to give the diamine monomer in $87 \%$ yield. Melting point $=256-258^{\circ} \mathrm{C}$. ${ }^{1} \mathrm{H}$ NMR (400 MHz, $\left.\mathrm{CDCl}_{3}, \delta\right): 2.07$ (s, 6H), 2.37 (s, 6H), 4.07 (br s, 4H), $5.12(\mathrm{~s}, 1 \mathrm{H}), 5.86(\mathrm{~s}, 1 \mathrm{H}), 6.89-6.98(\mathrm{~m}$, $4 \mathrm{H}), 7.24-7.31(\mathrm{~m}, 2 \mathrm{H}) .{ }^{13} \mathrm{C} \mathrm{NMR}\left(100 \mathrm{MHz}, \mathrm{CDCl}_{3}, \delta\right)$ : 13.0, 17.9, 47.3, 53.6, 117.2, 117.6, 122.9, 123.1, 123.6, 124.6, 125.3, 136.7, 139.7, 142.4, 145.7, 147.6. HRMS (ESI) $(\mathrm{m} / z)$ : calcd for $\mathrm{C}_{24} \mathrm{H}_{24} \mathrm{~N}_{2}$, 340.1939; found, $340.1930\left(\mathrm{M}^{+}\right)$. FTIR (powder, $\left.\nu, \mathrm{cm}^{-1}\right): 3450,3377(\mathrm{~N}-\mathrm{H}$ stretching), 3006 (aromatic C-H stretching), 2943 (aliphatic C-H stretching), 1621 ( $\mathrm{C}=\mathrm{C}$ ring stretching).

4.7. Typical Procedure for the Synthesis of the Polyimides. In a dry $10 \mathrm{~mL}$ reaction tube, a mixture of the diamine monomer $(1.0 \mathrm{mmol})$ and dianhydride monomer $(1.0$ $\mathrm{mmol})$ was stirred in dry $m$-cresol $(4 \mathrm{~mL})$ under a nitrogen atmosphere for $15 \mathrm{~min}$. After heating to $80{ }^{\circ} \mathrm{C}$, two drops of isoquinoline were added, and the reaction temperature was raised gradually to $200{ }^{\circ} \mathrm{C}$ and maintained at that temperature for $2 \mathrm{~h}$ under steady flow of nitrogen. During this period, water formed by the imidization reaction was removed by a stream of nitrogen. After cooling, the clear and viscous polyimide solution was added dropwise into stirred methanol, and the resulting fibrous polymer was collected by filtration, purified by reprecipitation twice from an appropriate solvent into methanol, and then dried under vacuum at $120{ }^{\circ} \mathrm{C}$ for $20 \mathrm{~h}$.

4.8. Synthesis of 6FDA-TMDAT. Following the above typical procedure, 6FDA-TMDAT was prepared from 6FDA and TMDAT as white powder in $78 \%$ yield after reprecipitation from chloroform into methanol. ${ }^{1} \mathrm{H}$ NMR $\left(400 \mathrm{MHz} \mathrm{CDCl}_{3}\right) \delta(\mathrm{ppm}): 2.08(\mathrm{~s}, 6 \mathrm{H}), 2.30(\mathrm{~s}, 6 \mathrm{H}), 5.40$ $(\mathrm{s}, 1 \mathrm{H}), 5.90(\mathrm{~s}, 1 \mathrm{H}), 7.03(\mathrm{~m}, 2 \mathrm{H}), 7.26(\mathrm{~s}, 2 \mathrm{H}), 7.39(\mathrm{~d}$, $2 \mathrm{H}), 7.89-8.01(\mathrm{~m}, 6 \mathrm{H})$. FT-IR (Membrane, $\left.\nu, \mathrm{cm}^{-1}\right): 1787$ (asym $\mathrm{C}=\mathrm{O}$, str), 1720 (sym $\mathrm{C}=\mathrm{O}$, str), $1361(\mathrm{C}-\mathrm{N}$, str), 849 (imide ring deformation). Analysis by GPC $\left(\mathrm{CHCl}_{3}\right): M_{\mathrm{n}}$ $=76,200 \mathrm{~g} \mathrm{~mol}^{-1}, M_{\mathrm{w}}=122,000 \mathrm{~g} \mathrm{~mol}^{-1}$ relative to polystyrene, $M_{\mathrm{w}} / M_{\mathrm{n}}=1.6$. BET surface area $=620 \mathrm{~m}^{2} \mathrm{~g}^{-1}$. TGA analysis: (nitrogen), initial weight loss due to thermal degradation commenced at $T_{\mathrm{d}} \approx 470{ }^{\circ} \mathrm{C}$. 
4.9. Synthesis of PMDA-TMDAT. Following the above procedure of 6FDA-TMDAT, a polymer was prepared from PMDA and TMDAT in $91 \%$ yield after reprecipitation from chloroform into methanol. ${ }^{1} \mathrm{H}$ NMR $\left(400 \mathrm{MHz}, \mathrm{CDCl}_{3}\right) \delta$ (ppm): $2.06(\mathrm{~s}, 6 \mathrm{H}), 2.29(\mathrm{~s}, 6 \mathrm{H}), 5.42(\mathrm{~s}, 1 \mathrm{H}), 5.90(\mathrm{~s}, 1 \mathrm{H})$, $7.05(\mathrm{~m}, 2 \mathrm{H}), 7.28-7.41(\mathrm{~m}, 2 \mathrm{H}), 8.46(\mathrm{~s}, 2 \mathrm{H})$. FTIR (membrane, $\nu, \mathrm{cm}^{-1}$ ): 1777 (asym $\mathrm{C}=\mathrm{O}$, str), 1719 (sym $\mathrm{C}=\mathrm{O}$, str), 1374 ( $\mathrm{C}-\mathrm{N}, \mathrm{str}), 857$ (imide ring deformation). Analysis by GPC $\left(\mathrm{CHCl}_{3}\right): M_{\mathrm{n}}=81,400 \mathrm{~g} \mathrm{~mol}^{-1}, M_{\mathrm{w}}=$ $125,000 \mathrm{~g} \mathrm{~mol}^{-1}$ relative to polystyrene, $M_{\mathrm{w}} / M_{\mathrm{n}}=1.54$. BET surface area $=720 \mathrm{~m}^{2} \mathrm{~g}^{-1}$. TGA analysis: (nitrogen), initial weight loss due to thermal degradation commenced at $T_{\mathrm{d}} \approx$ $500{ }^{\circ} \mathrm{C}$.

4.10. Synthesis of TPDA-TMDAT. Following the above procedure, TPDA-TMDAT was prepared from TPDA and TMDAT as yellow powder in $92 \%$ yield after reprecipitation from chloroform into methanol. ${ }^{1} \mathrm{H}$ NMR $\left(400 \mathrm{MHz} \mathrm{CDCl}_{3}\right)$ $\delta(\mathrm{ppm}): 1.72(\mathrm{~d}, 12 \mathrm{H}), 2.02(\mathrm{~s}, 6 \mathrm{H}), 2.24(\mathrm{~s}, 6 \mathrm{H}), 3.33-3.49$ $(\mathrm{m}, 2 \mathrm{H}), 5.35(\mathrm{~s}, 1 \mathrm{H}), 5.58(\mathrm{~s}, 1 \mathrm{H}), 6.93-7.08(\mathrm{~m}, 6 \mathrm{H})$, 7.21-7.36 (m, 12H). FT-IR (membrane, $\left.\nu, \mathrm{cm}^{-1}\right): 1780$ (asym $\mathrm{C}=\mathrm{O}$, str), 1720 (sym $\mathrm{C}=\mathrm{O}, \mathrm{str}), 1355(\mathrm{C}-\mathrm{N}, \mathrm{str}$ ), 837 (imide ring deformation). Analysis by GPC $\left(\mathrm{CHCl}_{3}\right): M_{\mathrm{n}}$ $=137,100 \mathrm{~g} \mathrm{~mol}^{-1}, M_{\mathrm{w}}=192,000 \mathrm{~g} \mathrm{~mol}^{-1}$ relative to polystyrene, $M_{\mathrm{w}} / M_{\mathrm{n}}=1.4$. BET surface area $=850 \mathrm{~m}^{2} \mathrm{~g}^{-1}$. TGA analysis: (nitrogen), initial weight loss due to thermal degradation commenced at $T_{\mathrm{d}} \approx 470{ }^{\circ} \mathrm{C}$.

4.11. Synthesis of NTDA-TMDAT. Following the above typical procedure, NTDA-TMDAT was prepared from 1,4,5,8NTDA and TMDAT in 99\% yield after reprecipitation from chloroform into methanol. ${ }^{1} \mathrm{H}$ NMR $\left(400 \mathrm{MHz}, \mathrm{CDCl}_{3}\right) \delta$ (ppm): $2.07(\mathrm{~s}, 6 \mathrm{H}), 2.27(\mathrm{~s}, 6 \mathrm{H}), 5.46(\mathrm{~s}, 1 \mathrm{H}), 5.92(\mathrm{~s}, 1 \mathrm{H})$, $7.00(\mathrm{~s}, 2 \mathrm{H}), 7.34-7.43(\mathrm{~m}, 4 \mathrm{H}), 8.79(\mathrm{~m}, 4 \mathrm{H})$. FT-IR $(\nu$, $\mathrm{cm}^{-1}$ ): 1713 (asym $\mathrm{C}=\mathrm{O}$, str), 1670 (sym $\left.\mathrm{C}=\mathrm{O}, \mathrm{str}\right), 1337$ (C-N, str), 849 (imide ring deformation). Analysis by GPC $\left(\mathrm{CHCl}_{3}\right): M_{\mathrm{n}}=104,000 \mathrm{~g} \mathrm{~mol}^{-1}, M_{\mathrm{w}}=156,000 \mathrm{~g} \mathrm{~mol}^{-1}$ relative to polystyrene, $M_{\mathrm{w}} / M_{\mathrm{n}}=1.5$. BET surface area $=790$ $\mathrm{m}^{2} \mathrm{~g}^{-1}$. TGA analysis: (nitrogen), initial weight loss due to thermal degradation commenced at $T_{\mathrm{d}} \approx 510{ }^{\circ} \mathrm{C}$.

4.12. Synthesis of BCDA-TMDAT. Following the above procedure, BCDA-TMDAT was prepared from BCDA and TMDAT in $95 \%$ yield after reprecipitation from DMAC into methanol. ${ }^{1} \mathrm{H}$ NMR (400 MHz, DMSO- $\left.d_{6}\right) \delta$ (ppm): 1.38$2.19(\mathrm{~m}, 12 \mathrm{H}), 3.37(\mathrm{~s}, 2 \mathrm{H}), 3.53(\mathrm{~s}, 4 \mathrm{H}), 5.59(\mathrm{br} \mathrm{s}, 1 \mathrm{H})$, 6.09 (br s, $1 \mathrm{H}), 6.42(\mathrm{~m}, 2 \mathrm{H}), 7.03-7.57(\mathrm{~m}, 6 \mathrm{H})$. FT-IR (membrane, $\nu, \mathrm{cm}^{-1}$ ): 1775 (asym $\mathrm{C}=\mathrm{O}$, str), 1704 (sym $\mathrm{C}=\mathrm{O}, \mathrm{str}), 1365$ (C-N, str), 877 (imide ring deformation). Analysis by GPC (DMF): $M_{\mathrm{n}}=132,100 \mathrm{~g} \mathrm{~mol}^{-1}, M_{\mathrm{w}}=$ $183,000 \mathrm{~g} \mathrm{~mol}^{-1}, M_{\mathrm{w}} / M_{\mathrm{n}}=1.38$. BET surface area $=610 \mathrm{~m}^{2}$ $\mathrm{g}^{-1}$. TGA analysis: (nitrogen), initial weight loss due to thermal degradation commenced at $T_{\mathrm{d}} \approx 450{ }^{\circ} \mathrm{C}$.

4.13. Film Preparation. Polymer solutions in either chloroform or DMAC $(2-3 \mathrm{w} / \mathrm{v} \%)$ were filtered by a 0.45 $\mu \mathrm{m}$ PTFE syringe filter into a flat glass Petri dish. Isotropic films were obtained by slow evaporation of the solvent at room temperature $\left(\mathrm{CHCl}_{3}\right)$ or at $80^{\circ} \mathrm{C}$ (DMAc) under flow of a nitrogen stream. The films were further dried under vacuum at $120{ }^{\circ} \mathrm{C}$ and then soaked in methanol for $24 \mathrm{~h}$, air-dried, and finally post-dried at $120{ }^{\circ} \mathrm{C}$ for $24 \mathrm{~h}$ under vacuum. Prior to the gas permeation tests, TGA experiments were performed to confirm complete solvent removal from the polymer films. Films with thickness of $50-60 \mu \mathrm{m}$ were used for gas permeability measurements.
4.14. Gas Permeation Measurements. Pure-gas permeation measurements were conducted with a customdesigned permeation system using the constant-volume/ variable-pressure method. The pure-gas permeabilities of $\mathrm{He}$, $\mathrm{H}_{2}, \mathrm{~N}_{2}, \mathrm{O}_{2}, \mathrm{CH}_{4}$, and $\mathrm{CO}_{2}$ were measured at $35^{\circ} \mathrm{C}$ and 2 bar.

\section{ASSOCIATED CONTENT}

\section{S Supporting Information}

The Supporting Information is available free of charge on the ACS Publications website at DOI: 10.1021/acsomega.8b01975.

Gas permeation testing procedure; solubility properties; FTIR spectra of 6FDA-TMDAT; NLDFT-derived pore size distribution; and crystallographic data of TMDNT (CCDC 1515556). These data can be obtained free of charge from The Cambridge Crystallographic Data Centre via www.ccdc.cam.ac.uk/data_request/cif (PDF)

\section{AUTHOR INFORMATION}

\section{Corresponding Author}

*E-mail: ingo.pinnau@kaust.edu.sa.

ORCID

Ingo Pinnau: 0000-0003-3040-9088

Notes

The authors declare no competing financial interest.

\section{ACKNOWLEDGMENTS}

This work was supported by funding from King Abdullah University of Science and Technology (KAUST).

\section{REFERENCES}

(1) Budd, P. M.; Ghanem, B. S.; Makhseed, S.; McKeown, N. B.; Msayib, K. J.; Tattershall, C. E. Polymers of Intrinsic Microporosity (PIMs): Robust, Solution-Processable, Organic Nanoporous Materials. Chem. Commun. 2004, 230-231.

(2) Mckeown, N. B.; Budd, P. M. Polymers of Intrinsic Microporosity (PIMs): Organic Materials for Membrane Separations, Heterogeneous Catalysis and Hydrogen Storage. Chem. Soc. Rev. 2006, 35, 675-683.

(3) McKeown, N. B.; Budd, P. M. Exploitation of Intrinsic Microporosity in Polymer-Based Materials. Macromolecules 2010, 43, 5163-5176.

(4) Thomas, J. C.; Trend, J. E.; Rakow, N. A.; Wendland, M. S.; Poirier, R. J.; Paolucci, D. M. Optical Sensor for Diverse Organic Vapors at ppm Concentration Ranges. Sensors 2011, 11, 3267-3280.

(5) Wang, Y.; McKeown, N. B.; Msayib, K. J.; Turnbull, G. A.; Samuel, I. D. W. Laser Chemosensor with Rapid Responsivity and Inherent Memory Based on a Polymer of Intrinsic Microporosity. Sensors 2011, 11, 2478-2487.

(6) McKeown, N. B.; Gahnem, B.; Msayib, K. J.; Budd, P. M.; Tattershall, C. E.; Mahmood, K.; Tan, S.; Book, D.; Langmi, H. W.; Walton, A. Towards Polymer-Based Hydrogen Storage Materials: Engineering Ultramicroporous Cavities within Polymers of Intrinsic Microporosity. Angew. Chem., Int. Ed. 2006, 45, 1804-1807.

(7) Ghanem, B. S.; Hashem, M.; Harris, K. D. M.; Msayib, K. J.; Xu, M.; Budd, P. M.; Chaukura, N.; Book, D.; Tedds, S.; Walton, A.; McKeown, N. B. Triptycene-Based Polymers of Intrinsic Microporosity: Organic Materials That Can Be Tailored for Gas Adsorption. Macromolecules 2010, 43, 5287-5294.

(8) Ramimoghadam, D.; Gray, E. M.; Webb, C. J. Review of Polymers of Intrinsic Microporosity for Hydrogen Storage Applications. Int. J. Hydrogen Energy 2016, 41, 16944-16965. 
(9) Fritsch, D.; Merten, P.; Heinrich, K.; Lazar, M.; Priske, M. High Performance Organic Solvent Nanofiltration Membranes: Development and Thorough Testing of Thin Film Composite Membranes Made of Polymers of Intrinsic Microporosity (PIMs). J. Membr. Sci. 2012, 401-402, 222-231.

(10) Tsarkov, S.; Khotimskiy, V.; Budd, P. M.; Volkov, V.; Kukushkina, J.; Volkov, A. Solvent Nanofiltration Through High Permeability Glassy Polymers: Effect of Polymer and Solute Nature. J. Membr. Sci. 2012, 423-424, 65-72.

(11) Wu, X. M.; Zhang, Q. G.; Soyekwo, F.; Liu, Q. L.; Zhu, A. M. Pervaporation Removal of Volatile Organic Compounds from Aqueous Solutions Using the Highly Permeable PIM-1 Membrane. AIChE J. 2016, 62, 842-851.

(12) Gao, L.; Alberto, M.; Gorgojo, P.; Szekely, G.; Budd, P. M. High-Flux PIM-1/PVDF Thin film Composite Membranes for 1Butanol/Water Pervaporation. J. Membr. Sci. 2017, 529, 207-214.

(13) Budd, P.; Msayib, K.; Tattershall, C.; Ghanem, B.; Reynolds, K.; Mckeown, N.; Fritsch, D. Gas Separation Membranes from Polymers of Intrinsic Microporosity. J. Membr. Sci. 2005, 251, 263269.

(14) Budd, P.; Mckeown, N.; Ghanem, B.; Msayib, K.; Fritsch, D.; Starannikova, L.; Belov, N.; Sanfirova, O.; Yampolskii, Y.; Shantarovich, V. Gas Permeation Parameters and Other Physicochemical Properties of a Polymer of Intrinsic Microporosity: Polybenzodioxane PIM-1. J. Membr. Sci. 2008, 325, 851-860.

(15) Song, J.; Du, N.; Dai, Y.; Robertson, G. P.; Guiver, M. D.; Thomas, S.; Pinnau, I. Linear High Molecular Weight Ladder Polymers by Optimized Polycondensation of Tetrahydroxytetramethylspirobisindane and 1,4-Dicyanotetrafluorobenzene. Macromolecules 2008, 41, 7411-7417.

(16) Du, N.; Robertson, G. P.; Song, J.; Pinnau, I.; Thomas, S.; Guiver, M. D. Polymers of Intrinsic Microporosity Containing Trifluoromethyl and Phenylsulfone Groups as Materials for Membrane Gas Separation. Macromolecules 2008, 41, 9656-9662.

(17) Thomas, S.; Pinnau, I.; Du, N.; Guiver, M. D. Pure- and MixedGas Permeation Properties of a Microporous Spirobisindane-based Ladder Polymer (PIM-1). J. Membr. Sci. 2009, 333, 125-131.

(18) Bezzu, C. G.; Carta, M.; Tonkins, A.; Jansen, J. C.; Bernardo, P.; Bazzarelli, F.; McKeown, N. B. A Spirobifluorene-Based Polymer of Intrinsic Microporosity with Improved Performance for Gas Separation. Adv. Mater. 2012, 24, 5930-5933.

(19) Li, P.; Chung, T. S.; Paul, D. R. Gas Sorption and Permeation in PIM-1. J. Membr. Sci. 2013, 432, 50-57.

(20) Carta, M.; Malpass-Evans, R.; Croad, M.; Rogan, Y.; Jansen, J. C.; Bernardo, P.; Bazzarelli, F.; McKeown, N. B. An Efficient Polymer Molecular Sieve for Membrane Gas Separations. Science 2013, 339, 303-307.

(21) Carta, M.; Croad, M.; Malpass-Evans, R.; Jansen, J. C.; Bernardo, P.; Clarizia, G.; Friess, K.; Lanč, M.; McKeown, N. B. Triptycene Induced Enhancement of Membrane Gas Selectivity for Microporous Tröger's Base Polymers. Adv. Mater. 2014, 26, 35263531.

(22) Ghanem, B. S.; Swaidan, R.; Ma, X.; Litwiller, E.; Pinnau, I. Energy-Efficient Hydrogen Separation by AB-Type Ladder-Polymer Molecular Sieves. Adv. Mater. 2014, 26, 6696-6700.

(23) Carta, M.; Bernardo, P.; Clarizia, G.; Jansen, J. C.; McKeown, N. B. Gas Permeability of Hexaphenylbenzene Based Polymers of Intrinsic Microporosity. Macromolecules 2014, 47, 8320-8327.

(24) Rose, I.; Carta, M.; Malpass-Evans, R.; Ferrari, M.-C.; Bernardo, P.; Clarizia, G.; Jansen, J. C.; McKeown, N. B. Highly Permeable Benzotriptycene-Based Polymer of Intrinsic Microporosity. ACS Macro Lett. 2015, 4, 912-915.

(25) Zhang, J.; Jin, J.; Cooney, R.; Zhang, S. Synthesis of Polymers of Intrinsic Microporosity Using an AB-Type Monomer. Polymer 2015, 57, 45-50.

(26) Ma, X.; Pinnau, I. A Novel Intrinsically Microporous Ladder Polymer and Copolymers Derived from 1,1',2,2'-Tetrahydroxytetraphenylethylene for Membrane-Based Gas Separation. Polym. Chem. 2016, 7, 1244-1248.
(27) Zhang, J.; Kang, H.; Martin, J.; Zhang, S.; Thomas, S.; Merkel, T. C.; Jin, J. The Enhancement of Chain Rigidity and Gas Transport Performance of Polymers of Intrinsic Microporosity via Intramolecular Locking of the Spiro-Carbon. Chem. Commun. 2016, 52, $6553-6556$

(28) Ghanem, B.; Alghunaimi, F.; Alaslai, N.; Ma, X.; Pinnau, I. New Phenazine-Containing Ladder Polymer of Intrinsic Microporosity from a Spirobisindane-Based AB-Type Monomer. RSC Adv. 2016, 6, 79625-79630.

(29) Rose, I.; Bezzu, C. G.; Carta, M.; Comesaña-Gándara, B.; Lasseuguette, E.; Ferrari, M. C.; Bernardo, P.; Clarizia, G.; Fuoco, A.; Jansen, J. C.; Hart, K. E.; Liyana-Arachchi, T. P.; Colina, C. M.; McKeown, N. B. Polymer Ultrapermeability from the Inefficient Packing of 2D Chains. Nat. Mater. 2017, 16, 932-937.

(30) Bower, G. M.; Frost, L. W. Aromatic Polyimides. J. Polym. Sci., Part A: Polym. Chem. 1963, 1, 3135-3150.

(31) Hoehn, H. H.; Richter, J. W. Aromatic Polyimide, Polyester and Polyamide Separation Membranes. U.S. Patent 3,899,309 A, 1975.

(32) Kim, T. H.; Koros, W. J.; Husk, G. R.; O’Brien, K. C. Relationship Between Gas Separation Properties and Chemical Structure in a Series of Aromatic Polyimides. J. Membr. Sci. 1988, $37,45-62$.

(33) Ayala, D.; Lozano, A. E.; de Abajo, J.; García-Perez, C.; de la Campa, J. G.; Peinemann, K.-V.; Freeman, B. D.; Prabhakar, R. Gas Separation Properties of Aromatic Polyimides. J. Membr. Sci. 2003, $215,61-73$.

(34) Xiao, Y.; Low, B. T.; Hosseini, S. S.; Chung, T. S.; Paul, D. R. The Strategies of Molecular Architecture and Modification of Polyimide-Based Membranes for $\mathrm{CO}_{2}$ Removal from Natural Gas-A Review. Prog. Polym. Sci. 2009, 34, 561-580.

(35) Liaw, D.-J.; Wang, K.-L.; Huang, Y.-C.; Lee, K.-R.; Lai, J.-Y.; Ha, C.-S. Advanced Polyimide Materials: Syntheses, Physical Properties and Applications. Prog. Polym. Sci. 2012, 37, 907-974.

(36) Weber, J.; Su, Q.; Antonietti, M.; Thomas, A. Exploring Polymers of Intrinsic Microporosity - Microporous, Soluble Polyamide and Polyimide. Macromol. Rapid Commun. 2007, 28, $1871-1876$

(37) Ghanem, B. S.; McKeown, N. B.; Budd, P. M.; Selbie, J. D.; Fritsch, D. High-Performance Membranes from Polyimides with Intrinsic Microporosity. Adv. Mater. 2008, 20, 2766-2771.

(38) Ghanem, B. S.; McKeown, N. B.; Budd, P. M.; Al-Harbi, N. M.; Fritsch, D.; Heinrich, K.; Starannikova, L.; Tokarev, A.; Yampolskii, Y. Synthesis, Characterization, and Gas Permeation Properties of a Novel Group of Polymers with Intrinsic Microporosity: PIMPolyimides. Macromolecules 2009, 42, 7881-7888.

(39) Rogan, Y.; Starannikova, L.; Ryzhikh, V.; Yampolskii, Y.; Bernardo, P.; Bazzarelli, F.; Jansen, J. C.; McKeown, N. B. Synthesis and Gas Permeation Properties of Novel Spirobisindane-Based Polyimides of Intrinsic Microporosity. Polym. Chem. 2013, 4, 38133820.

(40) Rogan, Y.; Malpass-Evans, R.; Carta, M.; Lee, M.; Jansen, J. C.; Bernardo, P.; Clarizia, G.; Tocci, E.; Friess, K.; Lanč, M.; McKeown, N. B. A Highly Permeable Polyimide with Enhanced Selectivity for Membrane Gas Separations. J. Mater. Chem. A. 2014, 2, 4874-4877.

(41) Ma, X.; Salinas, O.; Litwiller, E.; Pinnau, I. Pristine and Thermally-Rearranged Gas Separation Membranes from Novel oHydroxyl-Functionalized Spirobifluorene-Based Polyimides. Polym. Chem. 2014, 5, 6914-6922.

(42) McKeown, N. B.; Carta, M. Polymers, their Method of Manufacture and Use Thereof. U.S. Patent 9,212,261 B2, 2015.

(43) Wang, Z.; Wang, D.; Zhang, F.; Jin, J. Tröger's Base-Based Microporous Polyimide Membranes for High-Performance Gas Separation. ACS Macro Lett. 2014, 3, 597-601.

(44) Zhuang, Y.; Seong, J. G.; Do, Y. S.; Jo, H. J.; Cui, Z.; Lee, J.; Lee, Y. M.; Guiver, M. D. Intrinsically Microporous Soluble Polyimides Incorporating Tröger's Base for Membrane Gas Separation. Macromolecules 2014, 47, 3254-3262.

(45) Ghanem, B.; Alaslai, N.; Miao, X.; Pinnau, I. Novel 6FDABased Polyimides Derived from Sterically Hindered Tröger's Base 
Diamines: Synthesis and Gas Permeation Properties. Polymer 2016, 96, 13-19.

(46) Lee, M.; Bezzu, C. G.; Carta, M.; Bernardo, P.; Clarizia, G.; Jansen, J. C.; McKeown, N. B. Enhancing the Gas Permeability of Tröger's Base Derived Polyimides of Intrinsic Microporosity. Macromolecules 2016, 49, 4147-4154.

(47) Abdulhamid, M. A.; Ma, X.; Miao, X.; Pinnau, I. Synthesis and Characterization of a Microporous 6FDA-Polyimide Made from a Novel Carbocyclic Pseudo Tröger's Base Diamine: Effect of Bicyclic Bridge on Gas Transport Properties. Polymer 2017, 130, 182-190.

(48) Ma, X.; Abdulhamid, M. A.; Pinnau, I. Design and Synthesis of Polyimides Based on Carbocyclic Pseudo-Tröger's Base-Derived Dianhydrides for Membrane Gas Separation Applications. Macromolecules 2017, 50, 5850-5857.

(49) Sydlik, S. A.; Chen, Z.; Swager, T. M. Triptycene Polyimides: Soluble Polymers with High Thermal Stability and Low Refractive Indices. Macromolecules 2011, 44, 976-980.

(50) Cho, Y. J.; Park, H. B. High Performance Polyimide with High Internal Free Volume Elements. Macromol. Rapid Commun. 2011, 32, $579-586$.

(51) Ghanem, B. S.; Swaidan, R.; Litwiller, E.; Pinnau, I. UltraMicroporous Triptycene-Based Polyimide Membranes for HighPerformance Gas Separation. Adv. Mater. 2014, 26, 3688-3692.

(52) Swaidan, R.; Al-Saeedi, M.; Ghanem, B.; Litwiller, E.; Pinnau, I. Rational Design of Intrinsically Ultramicroporous Polyimides Containing Bridgehead-Substituted Triptycene for Highly Selective and Permeable Gas Separation Membranes. Macromolecules 2014, 47, 5104-5114.

(53) Wiegand, J. R.; Smith, Z. P.; Liu, Q.; Patterson, C. T.; Freeman, B. D.; Guo, R. Synthesis and Characterization of Triptycene-Based Polyimides with Tunable High Fractional Free Volume for Gas Separation Membranes. J. Mater. Chem. A 2014, 2, 13309-13320.

(54) Alghunaimi, F.; Ghanem, B.; Alaslai, N.; Swaidan, R.; Litwiller, E.; Pinnau, I. Gas Permeation and Physical Aging Properties of Iptycene Diamine-Based Microporous Polyimides. J. Membr. Sci. 2015, 490, 321-327.

(55) Weidman, J. R.; Guo, R. The Use of Iptycenes in Rational Macromolecular Design for Gas Separation Membrane Applications. Ind. Eng. Chem. Res. 2017, 56, 4220-4236.

(56) Alaslai, N.; Ma, X.; Ghanem, B.; Wang, Y.; Alghunaimi, F.; Pinnau, I. Synthesis and Characterization of a Novel Microporous Dihydroxyl-Functionalized Triptycene-Diamine-Based Polyimide for Natural Gas Membrane Separation. Macromol. Rapid Commun. 2017, 38, 1700303.

(57) Robeson, L. M. The Upper Bound Revisited. J. Membr. Sci. 2008, 320, 390-400.

(58) Tanaka, K.; Okano, M.; Toshino, H.; Kita, H.; Okamoto, K.-I. Effect of Methyl Substituents on Permeability and Permselectivity of Gases in Polyimides Prepared from Methyl-Substituted Phenylenediamines. J. Polym. Sci., Part B: Polym. Phys. 1992, 30, 907-914.

(59) Ellison, H.; Hey, D. H. 345. The Action of Benzaldehyde on o-, $\mathrm{m}$-, and $\mathrm{p}$-Xylene in the Presence of Aluminium Chloride. J. Chem. Soc. 1938, 1847-1853.

(60) Álvarez, C.; Lozano, A. E.; de la Campa, J. G. High-Productivity Gas Separation Membranes Derived from Pyromellitic Dianhydride and Nonlinear Diamines. J. Membr. Sci. 2016, 501, 191-198.

(61) Swaidan, R.; Ghanem, B.; Litwiller, E.; Pinnau, I. Physical Aging, Plasticization and Their Effects on Gas Permeation in Rigid Polymers of Intrinsic Microporosity. Macromolecules 2015, 48, 65536561.

(62) Low, Z.-X.; Budd, P. M.; McKeown, N. B.; Patterson, D. A. Gas Permeation Properties, Physical Aging, and Its Mitigation in High Free Volume Glassy Polymers. Chem. Rev. 2018, 118, 5871-5911.

(63) Swaidan, R.; Ghanem, B.; Pinnau, I. Fine-Tuned Intrinsically Ultramicroporous Polymers Redefine the Permeability/Selectivity Upper Bounds of Membrane-Based Air and Hydrogen Separations. ACS Macro Lett. 2015, 4, 947-951. 